\title{
Much ado about... everything: The plight of Southern European economies from a national competitiveness perspective
}

Rui Vinhas Da Silva

ISCTE - IUL - Lisbon University Institute

Natália Teixeira

Instituto Superior de Comunicação Empresarial

\section{Recommended Citation}

Da Silva, R. V., \& Teixeira, N. (2016). Much ado about... Everything: The plight of Southern European economies from a national competitiveness perspective. International Interdisciplinary Business-Economics Advancement Journal, 1(1), 19-31. 


\title{
Much Ado about... Everything: The Plight of Southern European Economies from a National Competitiveness Perspective
}

\author{
Rui Vinhas Da Silva ${ }^{1}$ and Natália Teixeira ${ }^{2}$
}

\author{
BRU- Business Research Unit \\ ISCTE - IUL - Lisbon University Institute, Portugal \\ ${ }^{1}$ rui.vinhas.silva@iscte.pt \\ Instituto Superior de Comunicação Empresarial, Portugal \\ ${ }^{2}$ n.teixeira@sapo.pt
}

\begin{abstract}
This paper identifies what are understood to be key drivers of country competitiveness. These are the institutional and structural conditions in an economy that are linked with the attainment of sustainable national competitive advantages through the creation of societal conditions that lead to a collective spirit of healthy competition at the heart of which lay competent organizations. The verification of these institutional and economic conditions of national competitiveness implies the development of a profound understanding of international markets and their aesthetic idiosyncrasies, with clear consequences to the promotion of exported goods and services of high aggregated value and the stimulation of domestic demand as well as the increasing sophistication of domestic business environments.
\end{abstract}

Keywords: exports, international finance, European Union, competitive advantages, value chains

\section{Introduction}

We contrast the relative position of European nations on competitiveness rankings by looking at two groups of nations in particular: southern economies (all Eurozone), and northern economies (Eurozone, non-Eurozone economies and non-EU). In particular, southern European nations have performed consistently poorly on widely acknowledged key drivers of country competitiveness and for the purposes of this paper we will look into how these economies rank in comparative terms to northern European nations, both Eurozone and non-Eurozone (EU and non-EU) on the following dimensions of competitiveness: effectiveness of anti-monopolistic policy, intensity of local competition, level of cluster development, quantity and quality of local suppliers, value chain breadth of exporting firms and nature of competitive advantages of domestic companies operating in international markets. In failing to comply with these key drivers of national competitiveness and by not systematically performing well on the determinants of economic competitiveness identified herein, economies will continue to fall in country competitiveness rankings with clear detrimental ramifications manifested on rapidly deteriorating indicators of social and human development. 


\section{Literature Review}

According to the Global Competitiveness Reports of the World Economic Forum, southern European economies have consistently ranked lower than their northern European counterparts on global competitiveness rankings tables published by this institution annually (2008-2013). In effect the decline of southern European economies has been consistent over a sustained period of time and in particular over the last decade, but the structural, institutional and behavioral antecedents to this turn of events had clearly been building up for some time.

The evidence points to poor performances and a consistent loss of competitiveness by southern European national economies when contrasted with their northern European counterparts, reflected in weak relative positions in global country competitiveness rankings. Flimsy hopes of future economic growth are thus a consequence of the low degree of conformity between the structural, institutional and behavioral realities of these economies on the one hand and the key drivers of modern country competitiveness on the other, with country competitiveness rankings being a mere reflection of that. In this context, there occurs a progressive alignment between the rankings positions that those nations occupy in national competitiveness league tables and the underlying economic and institutional realities that provide them with empirical grounding, with the former (rankings) ultimately having to reflect the latter (institutional and structural conditions). In these circumstances southern European nations will continue to lose competitiveness according to national rankings tables thus reflecting the gap between the structural and institutional DNA and behavioral idiosyncrasies of these economies on the one hand and the true and unforgiving determinants of global competitiveness on the other.

An analysis of the trends in country competitiveness rankings since 2008 (WEF, 2008-2013) corroborates the notion that an adjustment is under way, one tending to a closing of the gap between the relative position of these economies when observed through the lenses of global competitiveness league tables, and the structural and idiosyncratic realities that these rankings tend to reflect on the one hand and indicators of socio-economic development that the wealth generated by these economies is unable to justify on the other (Buckley, Pass, \& Prescott, 1988). Rankingsbased studies are by no means consensual and some authors do question their legitimacy (Lall, 2001).

Amidst a deep economic crisis and perhaps more importantly a profound structural, cultural and behavioral inadequacy of these economies when contrasted with the determinants of modern competitiveness in contemporary nations, a widening gap has been built between the structural make up of these nations, their institutions, and their economies, and the true and unambiguous drivers of country competitiveness (Delgado, Ketels, Porter, \& Stern, 2012). Under these circumstances, the future looks bleak for southern European economies as public debt/GDP ratios worsen by the day even under conditions of severe austerity and blind public sector cut-backs without a sign of sustained economic recovery in the process, precisely due to a failure of these economies to improve their performance on key dimensions of country competitiveness that is inextricably linked to economic growth (Herciu \& Ogrean, 2013).

On the other hand, an abrupt fall in competitiveness of these economies over a short period of time, at least in the context of the wider timeframe of the economic history of nations, traduces something a lot more sinister and worrying (Krugman, 1994). Some European economies simply 
appear to be signaling that they have definitely lost the global competitiveness train and this has to ring alarm bells right across the European landscape.

\section{Methodology}

The World Economic Forum (WEF) in its Global Competitiveness Report (GCR) has been tracking the competitive position of national economies for decades. Grounded empirically on quantitative data emanating from various credible sources, including the IMF, the World Bank and others, the WEF's annual GCR is also based on an Executive Survey, a qualitative methodological instrument, consisting of a scrutiny of many thousands of senior executives across the world, covering every country that features in the rather detailed and lengthy GCR's annual rankings tables (Önsel et al., 2009).

Table 1: Global Competitiveness Trend (Top 20 Ranking of the Most Competitive Nations and EU Economies Under International Intervention by the IMF, the European Commission and the European Central Bank Plus Italy and Cyprus)

\begin{tabular}{|c|c|c|c|c|c|}
\hline \multirow{2}{*}{ Country } & \multicolumn{5}{|c|}{ Competitiveness Ranking } \\
\hline & 2008 & 2009 & 2010 & 2011 & 2012 \\
\hline \# Switzerland \# & $2^{\text {nd }}$ & $1^{\text {st }}$ & $1^{\text {st }}$ & $1^{\text {st }}$ & $1^{\text {st }}$ \\
\hline Singapore & $5^{\text {th }}$ & $3^{\text {rd }}$ & $3^{\text {rd }}$ & $2^{\text {nd }}$ & $2^{\text {nd }}$ \\
\hline * Finland * & $6^{\text {th }}$ & $6^{\text {th }}$ & $7^{\text {th }}$ & $4^{\text {th }}$ & $3^{\text {rd }}$ \\
\hline+ Sweden + & $4^{\text {th }}$ & $4^{\text {th }}$ & $2^{\text {nd }}$ & $3^{\text {rd }}$ & $4^{\text {th }}$ \\
\hline * Netherlands * & $8^{\text {th }}$ & $10^{\text {th }}$ & $8^{\text {th }}$ & $7^{\text {th }}$ & $5^{\text {th }}$ \\
\hline * Germany * & $7^{\text {th }}$ & $7^{\text {th }}$ & $5^{\text {th }}$ & $6^{\text {th }}$ & $6^{\text {th }}$ \\
\hline USA & $1^{\mathrm{st}}$ & $2^{\text {nd }}$ & $4^{\text {th }}$ & $5^{\text {th }}$ & $7^{\text {th }}$ \\
\hline + United Kingdom + & $12^{\text {th }}$ & $13^{\text {th }}$ & $12^{\text {th }}$ & $10^{\text {th }}$ & $8^{\text {th }}$ \\
\hline Hong Kong SAR & $11^{\text {th }}$ & $11^{\text {th }}$ & $11^{\text {th }}$ & $11^{\text {th }}$ & $9^{\text {th }}$ \\
\hline Japan & $9^{\text {th }}$ & $8^{\text {th }}$ & $6^{\text {th }}$ & $9^{\text {th }}$ & $10^{\text {th }}$ \\
\hline Qatar & $26^{\text {th }}$ & $22^{\text {nd }}$ & $17^{\text {th }}$ & $14^{\text {th }}$ & $11^{\text {th }}$ \\
\hline + Denmark + & $3^{\text {rd }}$ & $5^{\text {th }}$ & $9^{\text {th }}$ & $8^{\text {th }}$ & $12^{\text {th }}$ \\
\hline Taiwan, China & $17^{\text {th }}$ & $12^{\text {th }}$ & $13^{\text {th }}$ & $13^{\text {th }}$ & $13^{\text {th }}$ \\
\hline Canada & $10^{\text {th }}$ & $9^{\text {th }}$ & $10^{\text {th }}$ & $12^{\text {th }}$ & $14^{\text {th }}$ \\
\hline \# Norway \# & $15^{\text {th }}$ & $14^{\text {th }}$ & $14^{\text {th }}$ & $16^{\text {th }}$ & $15^{\text {th }}$ \\
\hline+ Austria + & $14^{\text {th }}$ & $17^{\text {th }}$ & $18^{\text {th }}$ & $19^{\text {th }}$ & $16^{\text {th }}$ \\
\hline$*$ Belgium * & $19^{\text {th }}$ & $18^{\text {th }}$ & $19^{\text {th }}$ & $15^{\text {th }}$ & $17^{\text {th }}$ \\
\hline Saudi Arabia & $27^{\text {th }}$ & $28^{\text {th }}$ & $21^{\text {st }}$ & $17^{\text {th }}$ & $18^{\text {th }}$ \\
\hline Korea, Rep. & $13^{\text {th }}$ & $19^{\text {th }}$ & $22^{\text {nd }}$ & $24^{\text {th }}$ & $19^{\text {th }}$ \\
\hline Australia & $18^{\text {th }}$ & $15^{\text {th }}$ & $16^{\text {th }}$ & $20^{\text {th }}$ & $20^{\text {th }}$ \\
\hline * Ireland * & $22^{\text {nd }}$ & $25^{\text {th }}$ & $29^{\text {th }}$ & $29^{\text {th }}$ & $27^{\text {th }}$ \\
\hline * Spain * & $29^{\text {th }}$ & $33^{\text {rd }}$ & $42^{\text {nd }}$ & $36^{\text {th }}$ & $36^{\text {th }}$ \\
\hline * Italy * & $49^{\text {th }}$ & $48^{\text {th }}$ & $48^{\text {th }}$ & $43^{\text {rd }}$ & $42^{\text {nd }}$ \\
\hline * Portugal * & $43^{\text {rd }}$ & $43^{\text {rd }}$ & $46^{\text {th }}$ & $45^{\text {th }}$ & $49^{\text {th }}$ \\
\hline * Cyprus * & $40^{\text {th }}$ & $34^{\text {th }}$ & $40^{\text {th }}$ & $47^{\text {th }}$ & $58^{\text {th }}$ \\
\hline$*$ Greece * & $67^{\text {th }}$ & $71^{\text {st }}$ & $83^{\text {rd }}$ & $90^{\text {th }}$ & $96^{\text {th }}$ \\
\hline
\end{tabular}

Source: World Economic Forum (2008-2012)

Writing in black in grey background: northern European countries

Writing in white in black background: southern European countries

* Eurozone countries *, + Non-Eurozone EU countries +, \# Non-EU countries \#

Table 1 above shows the evolution of trends in national competitiveness rankings tables for the period 2008-2012 for the Top 20 most competitive nations globally and the four European nations that have been the object of intervention by the IMF, European Commission and the European Central Bank (Portugal, Ireland, Greece and Spain) of which three are southern European 
economies as well as Italy and Cyprus included here for the purposes of the study. The four intervened nations plus Italy and Cyprus appear here right after the Top 20 most competitive nations in ranking order of their relative position in the Global Competitiveness Report of 2013.

\section{Results}

Although European economies in general, tend to score well on institutional and infrastructural dimensions of national competitiveness, and on the critical drivers of innovation in the economy (Holsapple \& Singh, 2001), the less competitive southern European economies appear to continue to suffer from worrying and endemic concerns when it comes to such critical indicators of national competitiveness as the efficiency of labor markets but also that of goods and services markets (Lee \& Peterson, 2000).

Table 2: Effectiveness of Anti-Monopolistic Policy

\begin{tabular}{|c|c|c|c|c|c|}
\hline \multirow{2}{*}{ Country } & \multicolumn{5}{|c|}{ Policies that Effectively Promote Competition } \\
\hline & 2008 & 2009 & 2010 & 2011 & 2012 \\
\hline \# Switzerland \# & $19^{\text {th }}$ & $21^{\text {st }}$ & $23^{\text {rd }}$ & $21^{\text {st }}$ & $16^{\text {th }}$ \\
\hline Singapore & $20^{\text {th }}$ & $8^{\text {th }}$ & $9^{\text {th }}$ & $11^{\text {th }}$ & $5^{\text {th }}$ \\
\hline * Finland * & $6^{\text {th }}$ & $6^{\text {th }}$ & $4^{\text {th }}$ & $4^{\text {th }}$ & $4^{\text {th }}$ \\
\hline+ Sweden + & $4^{\text {th }}$ & $2^{\text {nd }}$ & $1^{\text {st }}$ & $1^{\text {st }}$ & $3^{\text {rd }}$ \\
\hline * Netherlands * & $1^{\text {st }}$ & $1^{\text {st }}$ & $2^{\text {nd }}$ & $2^{\text {nd }}$ & $1^{\mathrm{st}}$ \\
\hline * Germany * & $2^{\text {nd }}$ & $3^{\text {rd }}$ & $3^{\text {rd }}$ & $23^{\text {rd }}$ & $24^{\text {th }}$ \\
\hline USA & $8^{\text {th }}$ & $11^{\text {th }}$ & $17^{\text {th }}$ & $17^{\text {th }}$ & $17^{\text {th }}$ \\
\hline + United Kingdom + & $15^{\text {th }}$ & $17^{\text {th }}$ & $8^{\text {th }}$ & $3^{\text {rd }}$ & $9^{\text {th }}$ \\
\hline Hong Kong SAR & $53^{\text {rd }}$ & $84^{\text {th }}$ & $63^{\text {rd }}$ & $55^{\text {th }}$ & $55^{\text {th }}$ \\
\hline Japan & $21^{\text {st }}$ & $13^{\text {th }}$ & $7^{\text {th }}$ & $9^{\text {th }}$ & $15^{\text {th }}$ \\
\hline Qatar & $47^{\text {th }}$ & $39^{\text {th }}$ & $30^{\text {th }}$ & $27^{\text {th }}$ & $8^{\text {th }}$ \\
\hline + Denmark + & $3^{\text {rd }}$ & $5^{\text {th }}$ & $6^{\text {th }}$ & $5^{\text {th }}$ & $10^{\text {th }}$ \\
\hline Taiwan, China & $26^{\text {th }}$ & $22^{\text {nd }}$ & $21^{\text {st }}$ & $24^{\text {th }}$ & $19^{\text {th }}$ \\
\hline Canada & $16^{\text {th }}$ & $19^{\text {th }}$ & $14^{\text {th }}$ & $12^{\text {th }}$ & $21^{\text {st }}$ \\
\hline \# Norway \# & $9^{\text {th }}$ & $9^{\text {th }}$ & $11^{\text {th }}$ & $16^{\text {th }}$ & $11^{\text {th }}$ \\
\hline+ Austria + & $7^{\text {th }}$ & $12^{\text {th }}$ & $16^{\text {th }}$ & $13^{\text {th }}$ & $29^{\text {th }}$ \\
\hline * Belgium * & $12^{\text {th }}$ & $14^{\text {th }}$ & $13^{\text {th }}$ & $18^{\text {th }}$ & $30^{\text {th }}$ \\
\hline Saudi Arabia & $42^{\text {nd }}$ & $41^{\text {st }}$ & $28^{\text {th }}$ & $15^{\text {th }}$ & $12^{\text {th }}$ \\
\hline Korea, Rep. & $23^{\text {rd }}$ & $31^{\mathrm{st}}$ & $43^{\text {rd }}$ & $41^{\mathrm{st}}$ & $38^{\text {th }}$ \\
\hline Australia & $5^{\text {th }}$ & $7^{\text {th }}$ & $15^{\text {th }}$ & $22^{\text {nd }}$ & $18^{\text {th }}$ \\
\hline * Ireland * & $18^{\text {th }}$ & $20^{\text {th }}$ & $25^{\text {th }}$ & $26^{\text {th }}$ & $22^{\text {nd }}$ \\
\hline * Spain * & $33^{\text {rd }}$ & $32^{\text {nd }}$ & $33^{\text {rd }}$ & $36^{\text {th }}$ & $49^{\text {th }}$ \\
\hline * Italy * & $59^{\text {th }}$ & $76^{\text {th }}$ & $93^{\text {rd }}$ & $86^{\text {th }}$ & $100^{\text {th }}$ \\
\hline * Portugal * & $30^{\text {th }}$ & $43^{\text {rd }}$ & $49^{\text {th }}$ & $58^{\text {th }}$ & $68^{\text {th }}$ \\
\hline * Cyprus * & $27^{\text {th }}$ & $26^{\text {th }}$ & $26^{\text {th }}$ & $44^{\text {th }}$ & $42^{\text {nd }}$ \\
\hline * Greece * & $50^{\text {th }}$ & $59^{\text {th }}$ & $72^{\text {nd }}$ & $83^{\text {rd }}$ & $91^{\text {st }}$ \\
\hline
\end{tabular}

Source: World Economic Forum (2008-2012)

Of particular concern is the performance of these economies on the items that relate to the sophistication of business environments, items which are closely associated with a propensity for national economies to rank comparatively higher on country competitiveness tables than other nations characterized by less sophisticated business environments. This together with the innovation capabilities and competencies of a national economy constitute the true drivers of country competitiveness in modern economies (Fagerberg, 1988). If nations are not excelling on the dimensions of innovation and sophistication of business environments, then the future can only look bleak on the wellbeing of the citizens of these nations translated into the impoverishment of 
entire societies and expressed in the lowering of indicators of socio-economic development (Ross, Beath, \& Goodhue, 1996). This has been witnessed very rapidly by the national economies of Spain, Portugal and Greece.

If the key pillars of national competitiveness that measure the relative efficiency of labor markets and that of goods and services markets are indeed susceptible to change through the enactment of legislation to that end, in order for this to be effected, a reformist agenda of profound breadth and depth is required in southern European nations (Michie \& Sheehan, 2003). The same is applicable to changes in the quality and efficiency of the judicial systems in these nations, and their perceived inadequacy in arbitrating problems and issues in contemporary societies and modern economies operating in global settings (Rondinelli, 2003).

Table 3: Intensity of Local Competition

\begin{tabular}{|c|c|c|c|c|c|}
\hline \multirow{2}{*}{ Country } & \multicolumn{5}{|c|}{ Intensity of Competition in Most Local Industries } \\
\hline & 2008 & 2009 & 2010 & 2011 & 2012 \\
\hline \# Switzerland \# & $20^{\text {th }}$ & $27^{\text {th }}$ & $36^{\text {th }}$ & $24^{\text {th }}$ & $20^{\text {th }}$ \\
\hline Singapore & $30^{\text {th }}$ & $21^{\text {st }}$ & $28^{\text {th }}$ & $33^{\text {rd }}$ & $21^{\text {st }}$ \\
\hline * Finland * & $16^{\text {th }}$ & $31^{\text {st }}$ & $52^{\text {nd }}$ & $71^{\text {st }}$ & $68^{\text {th }}$ \\
\hline+ Sweden + & $14^{\text {th }}$ & $20^{\text {th }}$ & $5^{\text {th }}$ & $10^{\text {th }}$ & $22^{\text {nd }}$ \\
\hline * Netherlands * & $3^{\text {rd }}$ & $4^{\text {th }}$ & $10^{\text {th }}$ & $6^{\text {th }}$ & $1^{\mathrm{st}}$ \\
\hline * Germany * & $1^{\text {st }}$ & $1^{\mathrm{st}}$ & $2^{\text {nd }}$ & $9^{\text {th }}$ & $8^{\text {th }}$ \\
\hline USA & $4^{\text {th }}$ & $5^{\text {th }}$ & $16^{\text {th }}$ & $18^{\text {th }}$ & $18^{\text {th }}$ \\
\hline + United Kingdom + & $10^{\text {th }}$ & $6^{\text {th }}$ & $8^{\text {th }}$ & $3^{\text {rd }}$ & $5^{\text {th }}$ \\
\hline Hong Kong SAR & $7^{\text {th }}$ & $35^{\text {th }}$ & $32^{\text {nd }}$ & $14^{\text {th }}$ & $9^{\text {th }}$ \\
\hline Japan & $9^{\text {th }}$ & $8^{\text {th }}$ & $7^{\text {th }}$ & $4^{\text {th }}$ & $2^{\text {nd }}$ \\
\hline Qatar & $53^{\text {rd }}$ & $14^{\text {th }}$ & $3^{\mathrm{rd}}$ & $5^{\text {th }}$ & $12^{\text {th }}$ \\
\hline + Denmark + & $25^{\text {th }}$ & $11^{\text {th }}$ & $23^{\text {rd }}$ & $46^{\text {th }}$ & $29^{\text {th }}$ \\
\hline Taiwan, China & $5^{\text {th }}$ & $2^{\text {nd }}$ & $1^{\text {st }}$ & $1^{\text {st }}$ & $3^{\text {rd }}$ \\
\hline Canada & $23^{\text {rd }}$ & $24^{\text {th }}$ & $20^{\text {th }}$ & $21^{\text {st }}$ & $19^{\text {th }}$ \\
\hline \# Norway \# & $21^{\mathrm{st}}$ & $19^{\text {th }}$ & $27^{\text {th }}$ & $32^{\text {nd }}$ & $32^{\text {nd }}$ \\
\hline+ Austria + & $2^{\text {nd }}$ & $3^{\text {rd }}$ & $6^{\text {th }}$ & $8^{\text {th }}$ & $7^{\text {th }}$ \\
\hline * Belgium * & $6^{\text {th }}$ & $7^{\text {th }}$ & $4^{\text {th }}$ & $2^{\text {nd }}$ & $4^{\text {th }}$ \\
\hline Saudi Arabia & $50^{\text {th }}$ & $37^{\text {th }}$ & $24^{\text {th }}$ & $17^{\text {th }}$ & $14^{\text {th }}$ \\
\hline Korea, Rep. & $49^{\text {th }}$ & $39^{\text {th }}$ & $14^{\text {th }}$ & $15^{\text {th }}$ & $11^{\text {th }}$ \\
\hline Australia & $18^{\text {th }}$ & $17^{\text {th }}$ & $11^{\text {th }}$ & $7^{\text {th }}$ & $6^{\text {th }}$ \\
\hline * Ireland * & $39^{\text {th }}$ & $49^{\text {th }}$ & $51^{\text {st }}$ & $59^{\text {th }}$ & $40^{\text {th }}$ \\
\hline * Spain * & $15^{\text {th }}$ & $22^{\text {nd }}$ & $26^{\text {th }}$ & $23^{\text {rd }}$ & $23^{\text {rd }}$ \\
\hline * Italy * & $104^{\text {th }}$ & $103^{\text {rd }}$ & $84^{\text {th }}$ & $58^{\text {th }}$ & $67^{\text {th }}$ \\
\hline * Portugal * & $41^{\text {st }}$ & $46^{\text {th }}$ & $45^{\text {th }}$ & $56^{\text {th }}$ & $62^{\text {nd }}$ \\
\hline$*$ Cyprus * & $26^{\text {th }}$ & $16^{\text {th }}$ & $18^{\text {th }}$ & $30^{\text {th }}$ & $43^{\text {rd }}$ \\
\hline * Greece * & $52^{\text {nd }}$ & $68^{\text {th }}$ & $77^{\text {th }}$ & $82^{\text {nd }}$ & $95^{\text {th }}$ \\
\hline
\end{tabular}

Source: World Economic Forum (2008-2012)

This of course assumes particular importance in the context of the facilitation of foreign direct investment into southern European nations, in dire need of investment resource flows into their economies, as potential investors may perceive the legal and judicial idiosyncrasies of these nations as well as overly restrictive labor legislation and practices to be insurmountable obstacles when it comes to invest in these countries. In the end, in order for any change to work, it will take time, and a collective will to change, and this is both a political and educational problem in modern societies. Tables 2 and 3 show the rankings of nations with regards to the effectiveness of antimonopolistic policy and the degree of intensity of local competition, both at the very heart of industrial competitiveness in that the existence and enforcement of anti-monopolistic policy is 
naturally conducive to atomized sectors of economic activity, and a guarantor of individual players strongly contending for market position within a regulated and fair environment.

Key items of anti-monopolistic policy embedded in the political will to enforce policy measures often against powerful economic interest groups together with the promotion of an intensely competitive environment for firms to operate in, as well as matters of institutional transparency are important drivers of behavioral change of a kind that may be induced by the enactment of legislation, itself conducive to behavioral modification. However a change in the collective behavior of societies on items that make up for the pillar of sophistication of the business environment is something much more complex and difficult to effect (Porter \& Kramer, 2006). It takes generations before any change is felt as these matters are largely behavioral in nature and scope.

\section{Discussions}

A sophisticated business environment is a crucial dimension of modern economic competitiveness and a strong predictor of the sustained economic growth of nations. For business environments to be sophisticated there is a requirement for profound changes in the behavior of key stakeholder group involved at all stages of every value chain in the domestic market, but also critically in export sectors (Boltho, 1996).

Embedded in this thinking and of paramount importance to national competitiveness are the domestic market and consumers in it, as well as their role in the creation of an internal culture of profound and stringent exigency leading to sophisticated business environments (Porter, 2000). This however is widely acknowledged to be something whose attainment is not feasible from one day to the next as it takes time for behaviors to be internalized and made visible.

In the context of southern European nations and although these countries cannot be treated as if they are one single entity as they are in effect culturally heterogeneous, the problem with inducing sustainable behavioral change in stakeholders in an economy (Dess \& Miller, 1995), change of a kind that leads to more sophisticated business environments is that this entails the revoking of old paradigms that have governed the functioning of stagnant and inadequate structures for centuries.

This implies the removal of deep-rooted institutional structures and institutionalized beliefs, behaviors and practices, changing the attitudes of stakeholders, namely entrepreneurs, workers and consumers in every sector of economic activity, in short everyone. Behavioral change is therefore much more complex and difficult to effect, as the problem is not so much one of a prevailing legal or judicial framework but has instead an educational and cultural genesis.

The relative performance of an economy on the pillar of sophistication of the business environment traduces a higher or lower capacity of that nation for envisaging an economic model of competitiveness that is based on fundamental principles of value aggregation at each stage of each productive process, from production to distribution, from logistics to consumption, for every key link in every value chain where the economy aims to have a relevant presence in export markets (Keohane \& Milner, 1996).

This can only be achieved when key stakeholders are imbued in a philosophy of excellence that needs to transverse a whole economy and in reality an entire society. All of this implies a 
coordinated strategic approach to the economic competitiveness of a nation, an effort that requires time and commitment from key stakeholders, and foremost amongst these, policy-makers, entrepreneurs and workers who are required to buy into this philosophy (Porter, 1998).

Policy-makers are responsible for the definition of strategic guidelines and general orientations for the economy as it strives to become more and more competitive in the global arena, and should work to reduce ambiguity in the outcome of policy, simplifying bureaucracy, as well as ensuring a permanent scrutiny of the intended strategic trajectory and deviations from it.

National strategic purpose and intent has to be materialized through constant improvements in the critical competitiveness factors identified herein, not only in absolute terms, but also comparatively when contrasted with the performance of other nations on the same drivers of country competitiveness (Porter, 1998).

Key drivers of national competitiveness including the enactment of anti-monopolistic legislation and the creation of conditions for the inducement of higher local firm competition may be partly the work of government through the introduction of policy measures to that effect, but fundamentally it is the responsibility of firms to translate policy into action and thus take advantage of opportunities that are allowed by the enactment of anti-monopolistic policy.

Firms operationalize government anti-monopolistic policy measures by jumping into the opportunity conceded by the enactment of legislation favoring competition, thus ensuring higher levels of intensity in local competition, resulting in a more sophisticated and stronger domestic market with clear gains accruing to consumers. A more competitive economy ensues as an outcome of the enactment of policy to that effect and the subsequent behavior of key stakeholder groups when responding to competition-friendly legislation.

\section{Implementations}

The distance between southern European economies and their northern European counterparts is pronounced also when it comes to the key drivers of national competitiveness that constitute the levels of innovation and sophistication of business environments in an economy (Grant, 1996). In this context the level of cluster development in an economy is positively associated with the relative position of that economy in national competitiveness rankings tables.

This is evidenced by table 4 below where once again southern European nations tend to rank lower on the level of cluster development in their economies, meaning that firms in these economies tend to operate in an autonomous manner and outside any sector specific or countrywide strategic script, as is evidenced by an absence or a reduced number of integrated and economically viable clusters of economic activity. The existence of clusters of economic activity could instead potentially create synergies of economic importance to these nations as crucial links between firms in related and non-related clusters of economic activity should stand to benefit all concerned (Rosenfeld, 1997). 
Table 4: Level of Cluster Development

\begin{tabular}{|c|c|c|c|c|c|}
\hline \multirow[t]{2}{*}{ Country } & \multicolumn{5}{|c|}{ Level of Cluster Development } \\
\hline & 2008 & 2009 & 2010 & 2011 & 2012 \\
\hline \# Switzerland \# & $9^{\text {th }}$ & $9^{\text {th }}$ & $4^{\text {th }}$ & $8^{\text {th }}$ & $9^{\text {th }}$ \\
\hline Singapore & $3^{\mathrm{rd}}$ & $5^{\text {th }}$ & $5^{\text {th }}$ & $5^{\text {th }}$ & $3^{\text {rd }}$ \\
\hline * Finland * & $6^{\text {th }}$ & $7^{\text {th }}$ & $9^{\text {th }}$ & $4^{\text {th }}$ & $6^{\text {th }}$ \\
\hline+ Sweden + & $14^{\text {th }}$ & $10^{\text {th }}$ & $8^{\text {th }}$ & $7^{\text {th }}$ & $14^{\text {th }}$ \\
\hline * Netherlands * & $12^{\text {th }}$ & $13^{\text {th }}$ & $19^{\text {th }}$ & $20^{\text {th }}$ & $15^{\text {th }}$ \\
\hline * Germany * & $10^{\text {th }}$ & $11^{\text {th }}$ & $12^{\text {th }}$ & $13^{\text {th }}$ & $8^{\text {th }}$ \\
\hline USA & $2^{\text {nd }}$ & $2^{\text {nd }}$ & $6^{\text {th }}$ & $9^{\text {th }}$ & $12^{\text {th }}$ \\
\hline + United Kingdom + & $15^{\text {th }}$ & $12^{\text {th }}$ & $10^{\text {th }}$ & $11^{\text {th }}$ & $10^{\text {th }}$ \\
\hline Hong Kong SAR & $7^{\text {th }}$ & $4^{\text {th }}$ & $7^{\text {th }}$ & $6^{\text {th }}$ & $11^{\text {th }}$ \\
\hline Japan & $5^{\text {th }}$ & $1^{\mathrm{st}}$ & $2^{\text {nd }}$ & $3^{\text {rd }}$ & $5^{\text {th }}$ \\
\hline Qatar & $33^{\text {rd }}$ & $36^{\text {th }}$ & $21^{\text {st }}$ & $10^{\text {th }}$ & $7^{\text {th }}$ \\
\hline + Denmark + & $11^{\text {th }}$ & $14^{\text {th }}$ & $20^{\text {th }}$ & $16^{\text {th }}$ & $26^{\text {th }}$ \\
\hline Taiwan, China & $1^{\text {st }}$ & $6^{\text {th }}$ & $3^{\text {rd }}$ & $1^{\text {st }}$ & $1^{\text {st }}$ \\
\hline Canada & $16^{\text {th }}$ & $8^{\text {th }}$ & $11^{\text {th }}$ & $15^{\text {th }}$ & $16^{\text {th }}$ \\
\hline \# Norway \# & $20^{\text {th }}$ & $21^{\mathrm{st}}$ & $18^{\text {th }}$ & $19^{\text {th }}$ & $17^{\text {th }}$ \\
\hline+ Austria + & $17^{\text {th }}$ & $22^{\text {nd }}$ & $22^{\text {nd }}$ & $24^{\text {th }}$ & $18^{\text {th }}$ \\
\hline$*$ Belgium * & $27^{\text {th }}$ & $27^{\text {th }}$ & $26^{\text {th }}$ & $27^{\text {th }}$ & $20^{\text {th }}$ \\
\hline Saudi Arabia & $36^{\text {th }}$ & $40^{\text {th }}$ & $27^{\text {th }}$ & $21^{\text {st }}$ & $21^{\text {st }}$ \\
\hline Korea, Rep. & $8^{\text {th }}$ & $23^{\text {rd }}$ & $25^{\text {th }}$ & $28^{\text {th }}$ & $22^{\text {nd }}$ \\
\hline Australia & $34^{\text {th }}$ & $37^{\text {th }}$ & $35^{\text {th }}$ & $37^{\text {th }}$ & $37^{\text {th }}$ \\
\hline$*$ Ireland * & $26^{\text {th }}$ & $28^{\text {th }}$ & $32^{\text {nd }}$ & $34^{\text {th }}$ & $24^{\text {th }}$ \\
\hline * Spain * & $37^{\text {th }}$ & $32^{\text {nd }}$ & $36^{\text {th }}$ & $40^{\text {th }}$ & $41^{\mathrm{st}}$ \\
\hline * Italy * & $4^{\text {th }}$ & $3^{\text {rd }}$ & $1^{\text {st }}$ & $2^{\text {nd }}$ & $2^{\text {nd }}$ \\
\hline * Portugal * & $68^{\text {th }}$ & $57^{\text {th }}$ & $54^{\text {th }}$ & $58^{\text {th }}$ & $54^{\text {th }}$ \\
\hline * Cyprus * & $29^{\text {th }}$ & $30^{\text {th }}$ & $44^{\text {th }}$ & $42^{\text {nd }}$ & $45^{\text {th }}$ \\
\hline * Greece * & $88^{\text {th }}$ & $87^{\text {th }}$ & $99^{\text {th }}$ & $115^{\text {th }}$ & $126^{\text {th }}$ \\
\hline
\end{tabular}

Source: World Economic Forum (2008-2012)

\section{Limitations}

The relative position occupied by exporting companies in international value chains is a reflection of the ability of key sectors of economic activity in capturing the attention of foreign consumers with disposable income who are willing and able to pay more for products than what is suggested by their tangible or functional value. Perceived higher value in the minds of foreign consumers is attributable to excellent marketing and branding, a continuous focus on foreign buyers (industrial and consumers) and a permanent search for the enhancement of the understanding of their idiosyncrasies and how these shape buying decision-making (Salvatore, 2010).

Value chain breadth of exporting companies is thus a good indicator of national competitive ability as evidenced by table 5. Here again southern European economies fall well behind their northern European contenders, signifying a profound lack of understanding on the part of southern European key stakeholder constituencies and in particular entrepreneurs of the role and fundamental importance of value chain management and the requirement for firms to occupy relevant positions in these value chains. This typically means being close to the consumer where margins are higher and the potential for imitation by players from emerging economies lower but also having in key sectors of economic activity having a broad presence across entire value chains. Again this brings to the forefront the role of marketing and branding and its key importance to the competitiveness of contemporary economies (Cox, 1999). 
Table 5: Value Chain Breadth of Exporting Companies

\begin{tabular}{|c|c|c|c|c|c|}
\hline \multirow{2}{*}{ Country } & \multicolumn{5}{|c|}{ Broad Presence Across the Entire Value Chain } \\
\hline & 2008 & 2009 & 2010 & 2011 & 2012 \\
\hline \# Switzerland \# & $5^{\text {th }}$ & $3^{\text {rd }}$ & $4^{\text {th }}$ & $3^{\text {rd }}$ & $3^{\text {rd }}$ \\
\hline Singapore & $14^{\text {th }}$ & $12^{\text {th }}$ & $10^{\text {th }}$ & $10^{\text {th }}$ & $10^{\text {th }}$ \\
\hline * Finland * & $7^{\text {th }}$ & $9^{\text {th }}$ & $9^{\text {th }}$ & $7^{\text {th }}$ & $7^{\text {th }}$ \\
\hline+ Sweden + & $1^{\text {st }}$ & $4^{\text {th }}$ & $3^{\text {rd }}$ & $2^{\text {nd }}$ & $4^{\text {th }}$ \\
\hline * Netherlands * & $9^{\text {th }}$ & $6^{\text {th }}$ & $7^{\text {th }}$ & $6^{\text {th }}$ & $6^{\text {th }}$ \\
\hline * Germany * & $4^{\text {th }}$ & $1^{\text {st }}$ & $1^{\text {st }}$ & $4^{\text {th }}$ & $1^{\mathrm{st}}$ \\
\hline USA & $8^{\text {th }}$ & $11^{\text {th }}$ & $15^{\text {th }}$ & $14^{\text {th }}$ & $13^{\text {th }}$ \\
\hline + United Kingdom + & $15^{\text {th }}$ & $15^{\text {th }}$ & $11^{\text {th }}$ & $9^{\text {th }}$ & $8^{\text {th }}$ \\
\hline Hong Kong SAR & $11^{\text {th }}$ & $10^{\text {th }}$ & $13^{\text {th }}$ & $21^{\text {st }}$ & $17^{\text {th }}$ \\
\hline Japan & $2^{\text {nd }}$ & $2^{\text {nd }}$ & $2^{\text {nd }}$ & $1^{\text {st }}$ & $2^{\text {nd }}$ \\
\hline Qatar & $43^{\text {rd }}$ & $114^{\text {th }}$ & $85^{\text {th }}$ & $27^{\text {th }}$ & $23^{\mathrm{rd}}$ \\
\hline + Denmark + & $6^{\text {th }}$ & $8^{\text {th }}$ & $8^{\text {th }}$ & $12^{\text {th }}$ & $16^{\text {th }}$ \\
\hline Taiwan, China & $17^{\text {th }}$ & $16^{\text {th }}$ & $16^{\text {th }}$ & $17^{\text {th }}$ & $19^{\text {th }}$ \\
\hline Canada & $48^{\text {th }}$ & $38^{\text {th }}$ & $33^{\text {rd }}$ & $41^{\mathrm{st}}$ & $51^{\mathrm{st}}$ \\
\hline \# Norway \# & $39^{\text {th }}$ & $40^{\text {th }}$ & $30^{\text {th }}$ & $34^{\text {th }}$ & $44^{\text {th }}$ \\
\hline+ Austria + & $10^{\text {th }}$ & $7^{\text {th }}$ & $6^{\text {th }}$ & $5^{\text {th }}$ & $5^{\text {th }}$ \\
\hline$*$ Belgium * & $16^{\text {th }}$ & $17^{\text {th }}$ & $18^{\text {th }}$ & $16^{\text {th }}$ & $11^{\text {th }}$ \\
\hline Saudi Arabia & $33^{\text {rd }}$ & $29^{\text {th }}$ & $21^{\text {st }}$ & $22^{\text {nd }}$ & $24^{\text {th }}$ \\
\hline Korea, Rep. & $12^{\text {th }}$ & $13^{\text {th }}$ & $14^{\text {th }}$ & $19^{\text {th }}$ & $22^{\text {nd }}$ \\
\hline Australia & $72^{\text {nd }}$ & $78^{\text {th }}$ & $78^{\text {th }}$ & $75^{\text {th }}$ & $102^{\text {nd }}$ \\
\hline * Ireland * & $19^{\text {th }}$ & $19^{\text {th }}$ & $19^{\text {th }}$ & $15^{\text {th }}$ & $14^{\text {th }}$ \\
\hline * Spain * & $21^{\mathrm{st}}$ & $24^{\text {th }}$ & $25^{\text {th }}$ & $24^{\text {th }}$ & $26^{\text {th }}$ \\
\hline * Italy * & $13^{\text {th }}$ & $14^{\text {th }}$ & $12^{\text {th }}$ & $11^{\text {th }}$ & $12^{\text {th }}$ \\
\hline * Portugal * & $32^{\text {nd }}$ & $43^{\text {rd }}$ & $50^{\text {th }}$ & $44^{\text {th }}$ & $42^{\text {nd }}$ \\
\hline$*$ Cyprus * & $35^{\text {nd }}$ & $37^{\text {th }}$ & $44^{\text {th }}$ & $46^{\text {th }}$ & $36^{\text {th }}$ \\
\hline$*$ Greece $*$ & $53^{\text {rd }}$ & $58^{\text {th }}$ & $75^{\text {th }}$ & $83^{\text {rd }}$ & $94^{\text {th }}$ \\
\hline
\end{tabular}

Source: World Economic Forum (2008-2012)

Related to value chain breadth of exporting companies in an economy is the nature of competitive advantages of domestic firms in international markets. Here again and was the case with value chain breadth, the nature of firm competitive advantage directly correlates with a nation's ability to be more or less competitive in the world stage (Porter, 1998). In highly contested international markets the ability to attain sustainable competitive advantages is very difficult indeed as whatever confers a company, an export sector of activity or a whole economy with a competitive advantage may be easily eroded by virtue of technological obsolescence, sheer imitation, or improvement on the incumbent's competitive angle by newcomers into the market sector who are simply able to do it better and/or cheaper (Teece, 2003).

For an economy to have a set of competitive advantages that are difficult to replicate means that this economy will be more likely to rank highly in national competitiveness leagues as is evidenced by table 8 below, which again reiterates the precarious position of southern European economies with respect to the nature of competitive advantages when contrasted with their northern European counterparts.

It simply means that southern European nations in general have not been able to work on the finer aspects of value chain management that really matter for the competitiveness of contemporary economies (Kaplinsky \& Morris, 2001). Instead southern European economies remain evermore vulnerable to the challenges of emerging economies and in particular the impending threats of labour-based models of national competitiveness. In the light of the competitive reality of modern 
economies being stuck in the middle is a very dangerous position to be in as competitive advantages that are easy to replicate mean that these economies could easily see their incumbent positions of dominance usurped by newcomers into their traditional export markets leading to loss of position in these markets and declining levels of national competitiveness with corresponding falls in rankings tables (Dess \& Davis, 1984).

Table 6: Nature of Competitive Advantages of Domestic Companies in International Markets

\begin{tabular}{|c|c|c|c|c|c|}
\hline \multirow{2}{*}{ Country } & \multicolumn{5}{|c|}{ Sophistication of Products and Processes } \\
\hline & 2008 & 2009 & 2010 & 2011 & 2012 \\
\hline \# Switzerland \# & $2^{\text {nd }}$ & $2^{\text {nd }}$ & $2^{\text {nd }}$ & $2^{\text {nd }}$ & $1^{\mathrm{st}}$ \\
\hline Singapore & $16^{\text {th }}$ & $13^{\text {th }}$ & $14^{\text {th }}$ & $15^{\text {th }}$ & $14^{\text {th }}$ \\
\hline * Finland * & $6^{\text {th }}$ & $5^{\text {th }}$ & $4^{\text {th }}$ & $6^{\text {th }}$ & $5^{\text {th }}$ \\
\hline+ Sweden + & $5^{\text {th }}$ & $6^{\text {th }}$ & $5^{\text {th }}$ & $11^{\text {th }}$ & $12^{\text {th }}$ \\
\hline * Netherlands * & $9^{\text {th }}$ & $9^{\text {th }}$ & $8^{\text {th }}$ & $10^{\text {th }}$ & $9^{\text {th }}$ \\
\hline * Germany * & $1^{\text {st }}$ & $1^{\text {st }}$ & $3^{\text {rd }}$ & $4^{\text {th }}$ & $4^{\text {th }}$ \\
\hline USA & $12^{\text {th }}$ & $16^{\text {th }}$ & $19^{\text {th }}$ & $20^{\text {th }}$ & $18^{\text {th }}$ \\
\hline + United Kingdom + & $15^{\text {th }}$ & $15^{\text {th }}$ & $9^{\text {th }}$ & $5^{\text {th }}$ & $6^{\text {th }}$ \\
\hline Hong Kong SAR & $22^{\text {nd }}$ & $19^{\text {th }}$ & $16^{\text {th }}$ & $21^{\mathrm{st}}$ & $20^{\text {th }}$ \\
\hline Japan & $4^{\text {th }}$ & $3^{\text {rd }}$ & $1^{\text {st }}$ & $1^{\text {st }}$ & $2^{\text {nd }}$ \\
\hline Qatar & $36^{\text {th }}$ & $100^{\text {th }}$ & $58^{\text {th }}$ & $23^{\text {rd }}$ & $24^{\text {th }}$ \\
\hline+ Denmark + & $3^{\text {rd }}$ & $4^{\text {th }}$ & $6^{\text {th }}$ & $3^{\text {rd }}$ & $3^{\text {rd }}$ \\
\hline Taiwan, China & $24^{\text {th }}$ & $21^{\mathrm{st}}$ & $20^{\text {th }}$ & $18^{\text {th }}$ & $19^{\text {th }}$ \\
\hline Canada & $40^{\text {th }}$ & $48^{\text {th }}$ & $56^{\text {th }}$ & $71^{\mathrm{st}}$ & $83^{\text {rd }}$ \\
\hline \# Norway \# & $20^{\text {th }}$ & $24^{\text {th }}$ & $25^{\text {th }}$ & $28^{\text {th }}$ & $25^{\text {th }}$ \\
\hline+ Austria + & $7^{\text {th }}$ & $8^{\text {th }}$ & $13^{\text {th }}$ & $12^{\text {th }}$ & $7^{\text {th }}$ \\
\hline * Belgium * & $8^{\text {th }}$ & $10^{\text {th }}$ & $10^{\text {th }}$ & $9^{\text {th }}$ & $10^{\text {th }}$ \\
\hline Saudi Arabia & $51^{\mathrm{st}}$ & $39^{\text {th }}$ & $28^{\text {th }}$ & $27^{\text {th }}$ & $30^{\text {th }}$ \\
\hline Korea, Rep. & $13^{\text {th }}$ & $17^{\text {th }}$ & $18^{\text {th }}$ & $17^{\text {th }}$ & $16^{\text {th }}$ \\
\hline Australia & $37^{\text {th }}$ & $38^{\text {th }}$ & $59^{\text {th }}$ & $67^{\text {th }}$ & $62^{\text {nd }}$ \\
\hline * Ireland * & $18^{\text {th }}$ & $18^{\text {th }}$ & $17^{\text {th }}$ & $16^{\text {th }}$ & $17^{\text {th }}$ \\
\hline * Spain * & $27^{\text {th }}$ & $30^{\text {th }}$ & $32^{\text {nd }}$ & $31^{\mathrm{st}}$ & $33^{\text {rd }}$ \\
\hline * Italy * & $14^{\text {th }}$ & $12^{\text {th }}$ & $11^{\text {th }}$ & $7^{\text {th }}$ & $11^{\text {th }}$ \\
\hline * Portugal * & $55^{\text {th }}$ & $51^{\text {st }}$ & $45^{\text {th }}$ & $42^{\text {nd }}$ & $49^{\text {th }}$ \\
\hline * Cyprus * & $25^{\text {th }}$ & $22^{\text {nd }}$ & $23^{\mathrm{rd}}$ & $24^{\text {nd }}$ & $23^{\text {rd }}$ \\
\hline * Greece * & $34^{\text {th }}$ & $36^{\text {th }}$ & $50^{\text {th }}$ & $57^{\text {th }}$ & $57^{\text {th }}$ \\
\hline
\end{tabular}

Source: World Economic Forum (2008-2012)

In the end a loss in competitiveness translates into lower national productivity levels as the numerator of output in the output/input productivity ratio falls (Ciais, et al., 2005). Salaries are lowered to accommodate lowering productivities and key indicators of socio-economic and human development are jeopardized in these societies (Aiginger, 2004). This is indeed the plight of southern European societies and one that these economies will have to endure for the coming decades, unless they begin to tackle the real determinants of national competitiveness in an effective manner, instead of the customary obsession with austerity and public debt (Alesina \& Perotti, 1997).

\section{Conclusions}

Country competitiveness has at best been only paid occasional lip service to, and when reference is made to it, it is often in unsubstantiated ways, that are ideologically biased and party political in their approach and demeanor, when this should not be the case as the evidence is unambiguous on this most important of dimensions of economic policy. Much of this is attributable to an over- 
emphasis on macroeconomic policy to the detriment of the microeconomics of the firm, an overzealous focus on fiscal and spending policy, public deficits and debt an economy of financial speculation. This is even more surprising when many of these nations do not even possess any autonomy when it comes to monetary or exchange rate policy. They do not issue money, they have no control over interest rates and they share a common currency, rendering any idea of currency devaluation for the purposes of making export sectors in these economies more competitive on price in foreign markets anathema. Their hands are tied and yet none of this seems to deter the governments of these nations and wider society at large from focusing on macroeconomic policy and even monetary policy with little, if any attention paid to the vital issues of microeconomics.

The road to national competitiveness should also be straightforward, which means that in the final analysis the propensity for a nation to be more competitive than any other nation that competes with it for the same export markets or for the attraction of limited FDI inflows resides on its capacity for consistently excelling and performing better than other nations on key items that make up for the pillars of innovation and sophistication of the business environment. In addition to excelling on these key drivers of national competitiveness, the underlying institutional conditions that need to characterize the lives of these nations have to be anchored on a philosophy of facilitation of the functioning of economic activity that ultimately translates into higher levels of efficiency in labor and goods and services markets. The more competitive nations in the world are not those that export low value-added products, or that base their export strategies on low price competition, although there are emerging economies including China, that have adopted national competitiveness models anchored on low labor cost structures in largely labor intensive sectors of economic activity with overwhelming success. However, the demographic specificity of China, the never ending pool of cheap labor resources, a centralized political system founded on a unique brand of state capitalism grounded on feudal social structures, give it a singular character, one unparalleled by any other nation, and which perhaps and with the exception of India, traduces a model of economic development that no other nation can aspire to emulate.

Country economic competitiveness models that are based on low labor cost structures and that offer no relevant differentiation to aspirational consumers worldwide are simply not viable for European economies who wish to emulate and follow such models of national competitiveness. If firms operating in labor-intensive sectors of economic activity typified by cheap and abundant labor manage to consistently deliver above average profitability levels due to endless supplies of a critical input into production processes, labor, the sustainability for southern European economies of such a model of competitiveness is dubious to say the least. In all probability a model of national economic competitiveness anchored on low labor costs is only sustainable until such a time as someone somewhere else identifies an even cheaper labor source, which given the increasingly accentuated asymmetries in global labor markets, means in this day and age that it is only a question of time before someone comes up with a production algorithm that is sustained on even cheaper labor. This corroborates the vulnerability of any European economic model grounded on low costs of labor in labor-intensive sectors of economic activity to the low labor-cost models of firm competitiveness emanating from emerging economies. In effect, the nature of what currently constitutes competitive advantage in contemporary economies and how this feeds onto the strategic choice of a model of country economic competitiveness, clearly points the other way, to knowledge-based, innovation-driven models of economic competitiveness as the only way forward for modern economies. To fail to recognize this is to prolong the agony of economies and this is the case with the economies of southern European nations. 
Models of national competitiveness that are intended to be sustainable, anchored on labor-intensive sectors of economic activity and low labor costs, models that typify the economies of nations that are now emerging into the global scene are not viable for European economies. The crucial difference for emerging economies is that these are countries that from the viewpoint of the critical adequacy between their chosen models of competitiveness and the abundance of resources that are required to fulfill them are blessed with very favorable demographic trends, variables that guarantee uninterrupted flows of almost free labor. These models of economic competitiveness are only sustainable even for these emerging economies until and only until another even cheaper source comes along.

\section{References}

Aiginger, K. (2004). The three tier strategy followed by successful European countries in the 1990s. International Review of Applied Economic, 18(4), 399-422.

Alesina, A., \& Perotti, R. (1997). The welfare state and competitiveness. American Economic Review, 87(5), 921939.

Boltho, A. (1996). The assessment: International competitiveness. Oxford Review of Economic Policy, 12(3), 1-16.

Buckley, P. J., Pass, C. L., \& Prescott, K. (1988). Measures of international competitiveness: A critical survey. Journal of Marketing Management, 4(2), 175-200.

Ciais, P., Reichstein, M., Viovy, N., Granier, A., Ogée, J., Allard, V., \& Valentini, R. (2005). Europe-wide reduction in primary productivity caused by the heat and drought in 2003. Nature, 437(7058), 529-533.

Cox, A. (1999). Power, value and supply chain management. Supply Chain Management: An International Journal, 4(4), 167-175.

Delgado, M., Ketels, C., Porter, M. E., \& Stern, S. (2012). The determinants of national competitiveness (NBER Working Paper 18249). Cambridge, MA: National Bureau of Economic Research. Retrieved from http://www.nber.org/papers/w18249

Dess, G. G., Miller, A. (1995). Strategic management. New York, NY: McGraw-Hill.

Dess, G. G., \& Davis, P. S. (1984). Porter's (1980) generic strategies as determinants of strategic group membership and organizational performance. Academy of Management Journal, 27(3), 467-488.

Fagerberg, J. (1988). International Competitiveness. The Economic Journal, 98(391), 355-374.

Grant, R. M. (1996). Prospering in dynamically-competitive environments: Organizational capability as knowledge integration. Organization Science, 7(4), 375-387.

Herciu, M., \& Ogrean, C. (2013). International competitiveness of countries - Evidence for some developed and emerging economies. European Scientific Journal, 9(19), 264-270.

Holsapple, C. W., \& Singh, M. (2001). The knowledge chain model: Activities for competitiveness. Experts Systems with Applications, 20(1), 77-98.

Kaplinsky, R., \& Morris, M. (2001). A handbook for value chain research. Ottawa, CA: IDRC

Keohane, R. O., \& Milner, H. V. (1996). Internationalization and domestic politics. New York, NY: Cambridge University Press.

Krugman, P. (1994). Competitiveness: A dangerous obsession. Foreign Affairs, 73(2), 28-44.

Lall, S. (2001). Competitiveness indices and developing countries: An economic evaluation of the global competitiveness report. World Development, 29(9), 1501-1525.

Lee, S. M., \& Peterson, S. J. (2000). Culture, entrepreneurial orientation, and global competitiveness. Journal of World Business, 35(4), 401-416.

Michie, J., \& Sheehan, M. (2003). Labour market deregulation, 'flexibility'and innovation. Cambridge Journal of Economics, 27(1), 123-143.

Önsel, Ş., Ülengin, F., Ulusoy, G., Kabak, Ö., Topcu, Y. İ., \& Aktas, E. (2009). A decision support system to evaluate the competitiveness of nations. In N. Mastorakis \& J. Sakellaris (Eds.), Advances in numerical methods (pp. 113-125). London, UK: Springer.

Porter, M. E. (1998). Competitive advantages of nations (11 ${ }^{\text {th }}$ ed.). New York, NY: The Free Press

Porter, M. E. (2000). Location, competition, and economic development: Local clusters in a global economy. Economic Development Quarterly, 14(1), 15-34.

Porter, M. E., \& Kramer, M. R. (2006). Strategy and society, Harvard Business Review, 84(12), 78-92. 
Rondinelli, D. A. (2003). Promoting national competitiveness in a globalizing economy: The state's changing roles. In D. A. Rondinelli \& S. Cheema (Eds.), Reinventing government for the twenty-first century; state capacity in a globalizing society (pp. 33-59). Bloomfield, CT: Kumarian Press.

Rosenfeld, S. A. (1997). Bringing business clusters into the mainstream of economic development. European Planning Studies, 5(1), 3-23.

Ross, J. W., Beath, C. M., \& Goodhue, D. L. (1996). Develop long-term competitiveness through IT assets. Sloan Management Review, 38(1), 31-42.

Salvatore, D. (2010). Globalisation, international competitiveness and growth: Advanced and emerging markets, large and small countries. Journal of International Commerce, Economics and Policy, 1(1), 21-32.

Teece, D. J. (2003). Capturing value from knowledge assets: The new economy, markets for know-how and intangible assets. Essays on Technology Management and Policy, 40(3), 47-75.

WEF. (2008). The global competitiveness report 2009-2008. Retrieved from http://www3.weforum.org/docs/WEF_GlobalCompetitivenessReport_2008-09.pdf

WEF. (2009). The global competitiveness report 2010-2009. Retrieved from http://www3.weforum.org/docs/WEF_GlobalCompetitivenessReport_2009-10.pdf

WEF. (2010). The global competitiveness report 2011-2010. Retrieved from http://www3.weforum.org/docs/WEF_GlobalCompetitivenessReport_2010-11.pdf

WEF. (2011). The global competitiveness report 2012-2011. Retrieved from http://www3.weforum.org/docs/WEF_GCR_Report_2011-12.pdf

WEF. (2012). The global competitiveness report 2012-2013. Retrieved from http://www3.weforum.org/docs/WEF_GlobalCompetitivenessReport_2012-13.pdf 